\title{
UNDERSTANDING OF SPECIAL TEACHERS IN TEACHING CHILDREN WITH SPECIAL NEEDS AT INCLUSIVE SCHOOLS
}

\author{
Djadja Rahardja \\ Department of Special Education, Indonesian Unversity of Education, Indonesia \\ E-mail: djadjarahardja@yahoo.com
}

\begin{abstract}
This study aims to obtain an objective picture of understanding of special teachers of the concept of children with special needs, teaching, and the concept of inclusive education. This research uses descriptive method with data collection in the form of a questionnaire. Based on research results, there are three findings: 1) understanding of special teachers on the concept of children with special needs are at the translational level, while for the classification and their impact are not yet at the translation level, 2) understanding of the special teachers on planning, implementation, and evaluation of teaching children with special needs in inclusive settings are not already on the translational level; and 3) understanding of the special teachers on concepts, philosophies and policies related to inclusive education are not at the level of translation.
\end{abstract}

Keywords: special teacher, children with special needs, inclusive school

Society's view of the concept of children with special needs in the globalization era has changed. People who initially has the view that children with special needs is different with children in general, are now of the view that children with special needs is not substantially different from the children in general.

Changes that view turned out to grow a new concept in service and education of children with special needs. Three kinds of education services for children with special needs from segregation, integration to inclusion were conducted. The fact, that three type of services still be implemented (Florian, 2008), like that in Romania (Ghergut, 2011), in China (Deng \& Zhu, 2016). The shift in public thinking about children with special needs is in line with the emergence of the human rights movements that fight for their rights in all aspects of life including equal rights in or children with special needs obtaining educational opportunities. The government has provided support to the enactment of Regulation of Ministry of Education and Culture No. 002/01/1986 of Integrated Education for children with special needs, dated January 4, 1986, and Circular of Directorate of Basic Education, Ministry of Education and Culture No. 6718 /C/I/1989 of Expansion of Learning Opportunities in Public Schools for children with special needs.

A clear understanding of the concept of special needs children is an important basis to be able to organize educational services that are right for them. Kirk (1986: 5) argues that "people mistake in understanding these children will have an impact on how he is doing for their education".
In order to perform its function as a special teacher, they are expected to have a number of attitudes, knowledge and skills that can foster and develop the personality of children with special needs. Berit \& Skortjen (2001: 311) suggests a minimum requirement abilities and skills in teaching children with special needs, are: (1) understand special education in terms of philosophical, historical, and formal rules that the underlying; (2) the characteristics of the students; (3) the assessment, diagnosis, and evaluation; (4) materials and learning process; (5) planning and management of the learning environment; (6) skills in managing student behavior and social interaction; (7) communication, cooperation, and collaboration; and (8) the professionalization and ethics implementation.

Competencies should be owned and controlled by the special teacher in performing his daily duties at the school. Without mastery of various competencies above, the resulting performance will be weak and not meet expected goals.

Phenomenon in the field shows that the educational background of teachers in regular schools are not prepared to be a special teacher. Thus, an understanding of special teachers is relatively low. Similarly, a program specifically designed for teaching children with special needs in regular schools are not yet available, while the students that teachers face is in need of special education services, so that each student's needs cannot be met. Therefore, teachers in implementing educational services to children with special needs need to be asked. 
Based on the above phenomenon appears the problem of how understanding the special teachers to the basic concepts of teaching children with special needs in inclusive education settings? Understanding the special teachers to the basic concepts of teaching children with special needs will greatly affect the development potential of children with special needs.

\section{METHOD}

The purpose of this study is to obtain an objective picture of the understanding of special teachers specifically about the concept of children with special needs, teaching children with special needs, and the concept of inclusive education. The method used is descriptive method with the questionnaire as a data collection technique. Respondents were 46 teachers who teach children with special needs at inclusive schools and without special education background. They are the teachers who taught in regular schools at the elementary schools and junior high schools level. Data analysis technique used is descriptive statistical analysis techniques in the form of a percentage.

\section{FINDINGS AND DISCUSSIONS}

\section{Findings}

Understanding Of Special Teachers On Children With Special Needs.

Based on the data analysis has been done on teachers' understanding of the concept of children with special needs can be seen in Table 1 .

Table 1 : Understanding of Special Teachers on

Concept of Children with Special Needs

\begin{tabular}{cccc}
\hline No & Answer & $\begin{array}{c}\text { Frequency } \\
\text { (f) }\end{array}$ & $\begin{array}{c}\text { Percentage } \\
(\mathbf{\%})\end{array}$ \\
\hline 1 & Yes & 44 & 95,65 \\
2 & No & 0 & 0 \\
3 & Hesitant & 2 & 4,35 \\
\hline & Total & $\mathbf{4 6}$ & $\mathbf{1 0 0}$ \\
\hline
\end{tabular}

In connection with the teachers' understanding of the classification of special needs children can be seen in Table 2.

Table 2 : Understanding of Special Teachers on Classification of Children with Special Needs

\begin{tabular}{cccc}
\hline No & Answer & $\begin{array}{c}\text { Frequency } \\
(\mathbf{f})\end{array}$ & $\begin{array}{c}\text { Percentage } \\
(\mathbf{\%})\end{array}$ \\
\hline 1 & Yes & 38 & 82,60 \\
2 & No & 0 & 0 \\
3 & Hesitant & 8 & 17,40 \\
\hline & Total & $\mathbf{4 6}$ & $\mathbf{1 0 0}$ \\
\hline
\end{tabular}

Teachers' understanding of the impact on children with special needs can be seen in Table 3 .

Table 3 : Understanding of Special Teachers on Impact on Children with Special Needs

\begin{tabular}{cccc}
\hline No & Answer & $\begin{array}{c}\text { Frequency } \\
\text { (f) }\end{array}$ & $\begin{array}{c}\text { Percentage } \\
(\mathbf{\%})\end{array}$ \\
\hline 1 & Yes & 20 & 43,48 \\
2 & No & 3 & 06,52 \\
3 & Hesitant & 23 & 50,00 \\
\hline & Total & $\mathbf{4 6}$ & $\mathbf{1 0 0}$ \\
\hline
\end{tabular}

Understanding Of Special Teachers On Learning Of Children With Special Needs.

Understanding of special teachers on lesson plan for children with special needs can be seen in table 4 .

Table 4 : Understanding of Special Teachers on Lesson Plan for Children with Special Needs

\begin{tabular}{cccc}
\hline No & Answer & $\begin{array}{c}\text { Frequency } \\
(\mathbf{f})\end{array}$ & $\begin{array}{c}\text { Percentage } \\
(\mathbf{\%})\end{array}$ \\
\hline 1 & Yes & 3 & 6,52 \\
2 & No & 26 & 56,52 \\
3 & Hesitant & 17 & 36,96 \\
\hline & Total & $\mathbf{4 6}$ & $\mathbf{1 0 0}$ \\
\hline
\end{tabular}

Regarding to the implementation of learning for children with special needs can be seen in table 5 .

Table 5 : Understanding of Special Teachers on Implementation of Learning for Children with Special Needs

\begin{tabular}{cccc}
\hline No & Answer & $\begin{array}{c}\text { Frequency } \\
\text { (f) }\end{array}$ & $\begin{array}{c}\text { Percentage } \\
\text { (\%) }\end{array}$ \\
\hline 1 & Yes & 6 & 13.04 \\
2 & No & 25 & 54,35 \\
3 & Hesitant & 15 & $32 ; 61$ \\
\hline & Total & $\mathbf{4 6}$ & $\mathbf{1 0 0}$ \\
\hline
\end{tabular}

Understanding of special teachers on evaluation used in learning for children with special needs can be seen in table 6 .

Table 6 : Understanding of Special Teachers on Learning Evaluation for Children with Special Needs

\begin{tabular}{cccc}
\hline No & Answer & $\begin{array}{c}\text { Frequency } \\
\text { (f) }\end{array}$ & $\begin{array}{c}\text { Percentage } \\
(\mathbf{\%})\end{array}$ \\
\hline 1 & Yes & 7 & 15,21 \\
2 & No & 25 & 54,35 \\
3 & Hesitant & 14 & 30,44 \\
\hline & Total & $\mathbf{4 6}$ & $\mathbf{1 0 0}$ \\
\hline
\end{tabular}


Understandng Of Special Teachers On Inclusive Education

Understanding of special teachers on concept of inclusive education can be seen in table 7 .

Table 7 : Understanding of Special Teachers on Concept of Inclusive Education

\begin{tabular}{cccc}
\hline No & Answer & $\begin{array}{c}\text { Frequency } \\
\text { (f) }\end{array}$ & $\begin{array}{c}\text { Percentage } \\
(\mathbf{\%})\end{array}$ \\
\hline 1 & Yes & 6 & 13.04 \\
2 & No & 25 & 54,35 \\
3 & Hesitant & 15 & $32 ; 61$ \\
\hline & Total & $\mathbf{4 6}$ & $\mathbf{1 0 0}$ \\
\hline
\end{tabular}

The understanding of special teachers about inclusive education philosophies can be seen in Table 8

Table 8 : Understanding of Special Teachers About Philosophies of Inclusive Education

\begin{tabular}{cccc}
\hline No & Answer & $\begin{array}{c}\text { Frequency } \\
(\mathbf{f})\end{array}$ & $\begin{array}{c}\text { Percentage } \\
(\mathbf{\%})\end{array}$ \\
\hline 1 & Yes & 22 & 47,82 \\
2 & No & 5 & 10,86 \\
3 & Hesitant & 19 & 41,32 \\
\hline & Total & $\mathbf{4 6}$ & $\mathbf{1 0 0}$ \\
\hline
\end{tabular}

Special teachers' understanding of policies related to inclusive education can be seen in Table 9

Table 9: Understanding of Special Teachers on Policies Related to Inclusive Education

\begin{tabular}{lllc}
\hline No & Answer & \multicolumn{1}{c}{$\begin{array}{c}\text { requency } \\
\text { (f) }\end{array}$} & $\begin{array}{c}\text { Percentage } \\
(\%)\end{array}$ \\
\hline 1 & Yes & 10 & 21,73 \\
2 & No & 6 & 13,04 \\
3 & Hesitant & 30 & 65,23 \\
\hline & Total & 46 & 100 \\
\hline
\end{tabular}

\section{Discussion}

Referring to the table 1, it appears that in most cases $(95.65 \%)$ special teachers acknowledge that they have understood concept of children with special needs, a small portion (4.35\%) admit they hesitate in understanding the concept of children with special needs. No one admits that they do not understand the concept of children with special needs. The results show that conceptually the special teachers has understood what is meant by children with special needs. This is evident from the percentage figures, which are $95.65 \%$ or 44 out of 46 special teachers who has understood the notion of children with special needs. This means that they are able to express correctly on the definition of children with special needs with its own language, to interpret the concept of children with special needs, and is able to explain the abstract concept of children with special needs to be more concrete. Overview achievement of understanding of the concept of special needs children in the special teachers when linked with the concept of understanding according to Bloom (1981), special teachers understanding of the concept of special needs children are at the translational level.

According to the table 2, it can be explained that the majority $(82.60 \%)$, special teachers specifically states have to understand the type or classification of children with special needs, and no one claimed not to understand the classification of children with special needs. While stating hesitant as many as 8 people $(17.40 \%)$. This means that conceptually special teachers has understood what is meant by the classification of children with special needs.

With an understanding of special teachers about the classification of children with special needs as many as 38 people $(82.6 \%)$, and no one who does not understand the classification of children with special needs, this illustrates that they are able to express properly on the classification of children with special needs with their own sentences, is able to interpret and explain concretely about the classification of children with special needs. It was concluded that most of the special teachers understanding of the classification of children with special needs at the stage of translational level (Bloom, 1981).

Referring to the table 3, it appears that as many as 20 people (43.48\%) special teachers has to understand the impact on children with special needs, as many as 3 people $(6.52 \%)$ claimed not to understand the impact on children with special needs. Meanwhile, the majority of them $(50 \%)$ expressed hesitation in understanding the impact on children with special needs.

The analysis showed that most of the special teachers still requires knowledge of the effects that occur in children with special needs. This is shown by the percentage figure of $50 \%$ were undecided. This means that they have not been able to state precisely about the effects that occur in children with special needs with the own language and the meanings of the concepts contained in the impact. It can be concluded that the special teachers cannot be able to translate the impact on children with special needs. When linked with the concept of understanding Bloom (1981), then the understanding of special teacher particular the impacts that occur in children with special needs has not reached the level of translation.

Based on the table 4, it appears that in general $(56.52 \%)$ special teachers did not understand the lesson plans for children with special needs. A total 
of 17 people $(36.96 \%)$ said that they still hesitate in understanding the lesson plans for children with special needs, as well as a small portion $(6.52 \%)$ of the study subjects admit have understood the lesson plans for children with special needs.

Incomprehension special teachers about lesson planning for children with special needs as many as 26 people $(56.52 \%)$ illustrates that they have not been able to declare the learning plan for children with special needs with the sentence itself, has not been able to interpret and have not been able to explain in concrete terms about the learning plan for the child with special needed. Based on the concept of understanding Bloom (1981), then the understanding of special teachers about lesson plan for children with special needs has not reached the level of translation.

The table 5 shows that the majority $(54,35 \%)$ special teachers specifically acknowledge that they do not understand the implementation of learning for children with special needs; while as many as 15 people $(32.61 \%)$ said that they still hesitate in understanding the implementation of learning for children with special needs. A small portion (13.04\%) out of 46 special teachers have understand the implementation of learning for children with special needs.

Results of the analysis showed lack special teacher about implementation of learning for children with special needs as many as 25 people $(54.35 \%)$, meaning that they have not been able to state precisely about the implementation of learning for children with special needs with the sentence itself, has not been able to interpret and have not been able to explain concretely on the implementation of learning for children with special needs. Based on the concept of understanding Bloom (1981), understanding of special teachers in implementing the learning for children with special needs has not reached the level of translation.

Referring to table 6 , that the majority $(54.35 \%)$ special teachers do not understand the evaluation of learning for children with special needs. A total of 14 people $(30.44 \%)$ said that they still hesitate in understanding the evaluation of learning for children with special needs. A small portion (15.21\%) admit to having to understand evaluation of learning for children with special needs. The analysis showed that the special teachers misunderstandings about evaluation of learning for children with special needs as many as 25 people $(54.35 \%)$ means that they have not able to express correctly on evaluation of learning for children with special needs with the own sentences, has not been able to interpret and cannot explain in concrete terms on the evaluation of learning for children with special needs. Nevertheless, there are still some special teachers who have understood the evaluation of learning for children with special needs. Based on the level of understanding Bloom (1981), then the understanding of special teachers about evaluation of learning for children with special needs has not reached the level of translation.

According to the table 7, it appears that in general, as many as 30 people $(65.22 \%)$, special teachers have to understand the concept or understanding of inclusive education; fraction (13.04\%) did not understand the concept of inclusive education. A total of 10 people $(21.74 \%)$ said that they still hesitate in understanding the concept of inclusive education.

Conceptually special teachers have to understand the concept of inclusive education. It is characterized by a high performance of $65.22 \%$. This means that they are able to express correctly on inclusive education and the understanding of the structure of own language and to make sense of the concept inclusive education appropriately. If linked to the concept of understanding Bloom (1981), most of the candidates understanding of the special teachers about the notion of inclusive education at the level of translation, and the fraction is not yet at the level of translation.

Referring to table 8 shown that as many as 22 people $(47.82 \%)$ special teacher has to understand the philosophy of inclusive education; and as many as 19 people $(41.32 \%)$ are still undecided in understanding the philosophy of inclusive education. A small portion $(10.86 \%)$ claimed not to understand the philosophy of inclusive education.

The analysis shows that there are a lot of special teachers who understand the philosophy of inclusive education (47.82\% or 22 people), but some are still hesitant in understanding the philosophy, as shown by the percentage figure of $41.32 \%$ or 19 people from respondents, and amounted to $10.86 \%$ who do not understand the philosophy of inclusive education. This means that special teachers are able to express correctly on the philosophy of inclusive education through their own sentences, are able to interpret the concepts contained in the philosophy of inclusive education and are able to explain the abstract concept of the philosophy of inclusive education becomes more concrete. Based on the level of understanding Bloom (1981), then the understanding of special teachers on the philosophy of inclusive education at the level of translation.

According to the table 9, it appears that as many as 10 people $(21.73 \%)$ special teacher has to understand the policies related to inclusive education, while as many as 6 people (13.04\%) states do not understand the policies related to inclusive education, majority $(65.23 \%)$ or as many as 30 special teachers was hesitant in understanding the policies related to inclusive education.

The above data shows that most of the special teacher knowledge and understanding of policies 
related to inclusive education, as shown by the percentage figure of $65.23 \%$ of the study subjects admitted they hesitate in understanding the policies relating to inclusive education, and amounted to $13.04 \%$ who do not understand the policy of inclusive education. This means that teachers have not been able specifically stated correctly on policies relating to inclusive education in their own language structure, has not been able to interpret the concepts contained in the policy on inclusive education and have not been able to explain the concept of inclusive education policy on a more concrete way. Based on the level of understanding Bloom (1981), then the understanding of special teachers of the policies related to inclusive education is not yet at the level of translation.

\section{CONCLUSION AND SUGGESTION}

Understanding the special teachers about the concept of children with special needs are at the translational level, while for the type or classification of children with special needs and their impact is not yet at the level of translation. Understanding of the special teachers about planning, implementation, and evaluation of teaching children with special needs in

\section{REFERENCES:}

Berit, H.J. \& Skortjen, D. M. (2001). Education-Special Needs Education An Introduction. Oslo: Unifub.

Bloom, BS., Madaus, GF., Hasting, JT. (1981) Evaluating to Improve Learning. USA: Mc.Grow Hill, Inc.

Deng, M., \& Zhu, X. (2016). Special education reform towards inclusive education: blurring or expanding boundaries of special and regular education in China. Journal of Research in Special Educational Needs, 16(S1), 994-998.

Departemen Pendidikan Nasional (2002). Kebijakan Direktorat PLB tentang Layanan Inklusif bagi Anak Berkebutuhan Pendidikan Khusus. Jakarta: Depdiknas. inclusive settings are not already on the translational level. Understanding of special teachers about the concept, philosophy, and policies related to inclusive education is not at the level of translation.

Limited knowledge and understanding of the special teachers about the concepts of children with special needs, teaching children with special needs, and concepts of inclusive education, partly due to lack of knowledge received in college before. The material is also very limited given only one half as much as three credits. Therefore, universities in particular majors or special education courses should be able to improve or optimize the weight of the material in both the education and children's learning specifically on inclusion setting.

Given the expectations suggested by the special teacher specialized in this research is accompanied by several practical considerations, the increased knowledge and understanding of the

special teacher is an essential and it will be realized if the competent institutions, especially development centers implement teachers make plans for education and training activities in the field of special education inclusion setting.

Florian, L. (2008). Inclusion: special or inclusive education: future trends. British Journal of Special Education, 35(4), 202-208.

Ghergut, A. (2011). Education of children with special needs in Romania; attitudes and experiences. Procedia-Social and Behavioral Sciences, 12, 595-599.

Kirk, A.S. \& Gallagher, J.J. (1986) Educating Exceptional Children. Boston: Houghton Mifflin Company 